\title{
obituary
}

\section{Jørn Utzon:}

\section{$1918-2008$}

Jørn Utzon, designer of Sydney Opera House, the most famous and controversial building of the twentieth-century that unwittingly ushered in the contemporary fascination with 'iconic' buildings, died at his home in Denmark on 5 December 2008 at the age of ninety.

Born in 1918 in Copenhagen, Jørn Utzon was brought up in Aalborg and Helsingør where his father Aage, a naval architect, ran the shipyards. He was happiest outdoors, hunting and sailing with his father and friends, and did not perform well academically, failing to achieve the entry standards for his intended career as a navy officer. He did, however, have a talent for drawing and his uncle, Einar Utzon-Frank, a sculptor and professor at the Royal Danish Academy of Fine Arts, suggested he apply to study architecture.

After completing his Diploma project in 1942 Utzon married Lis Fenger and escaped the German occupation of Denmark by working in Stockholm - briefly for Hakon Ahlberg, then for Poul Hedquist, who had taken over Gunnar Asplund's practice. In 1944 Utzon returned to Copenhagen to set up his own practice but found commissions hard to come by. He went to Helsinki and worked for Alvar Aalto for six weeks, spent some time in a family business in Morocco, worked for a lighting company and executed small utilitarian projects secured through an engineer-friend. He entered competitions, alone and with various collaborators, including his friends Tobias Faber and the Norwegian Arne Korsmo, whom he had met in Hedquist's office. Korsmo's circle of talented young architects in Oslo included Geir Grung (with

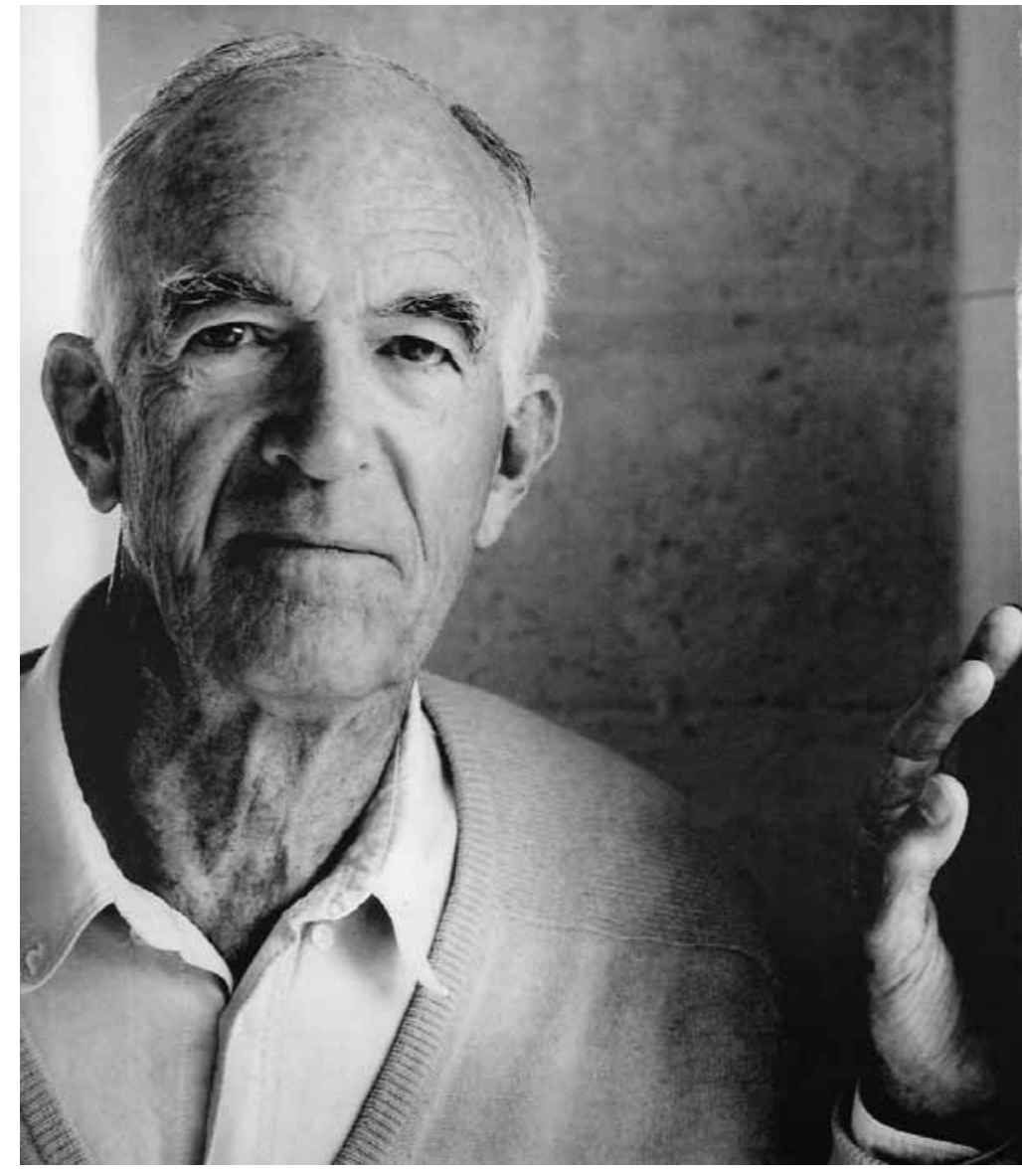

1 Portrait of Jørn Utzon taken in Can Lis, his first home on Majorca

whom Utzon later travelled in

China) and Sverre Fehn.

In 1949 the Utzons and Korsmos journeyed to the USA and from there down to Mexico to explore the Mayan sites. The experience of escaping the claustrophobia of the jungle by climbing up the stepped temples to experience the tree canopy disappearing to the horizon was exhilarating (arq 6/2, pp. 144-157). In response Utzon sketched a house consisting of layered platforms surmounted by fluttering, leaf-like roofs, and an idea for an airport that housed the aircraft in a hollow platform below the public concourses. Although its potential now hit him with particular force, a similar parti had informed an impressive entry to the 1946 competition for the burned-out Crystal Palace site at Sydenham and, at a much smaller scale, was deployed in 1953 for the Langelinie Pavilion [2] at the entrance to Copenhagen Harbour.

In 1952 Utzon built a house for his growing family at Hellebaek which the leading Danish 
modernist, Arne Jacobsen, visited during construction: he was heard to mutter under his breath, 'Hell, he's better than I am.' Two years later Utzon won a competition for new ideas for housing in Skåne in southern Sweden, where he proposed courtyard houses that could grow and change in response to their owners' needs. The idea was beguiling but impractical - the enclosing walls were expensive, and the banks wouldn't lend money to build them - but, suitably compacted, it soon yielded the masterly Kingo (1957-9) [3] and Fredensborg (1962-5)) courtyard houses.

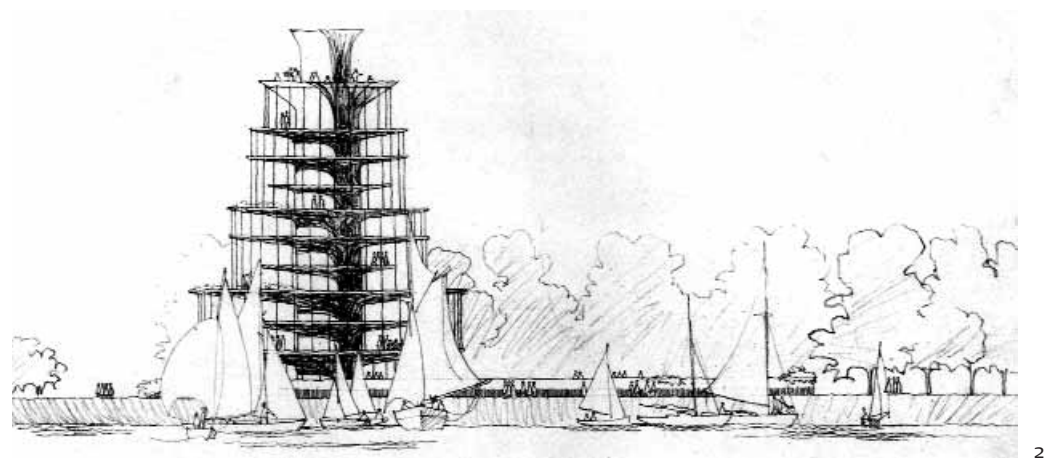

2 Perspective of entry for the Langelinie Pavilion, Copenhagen Harbour, 1953

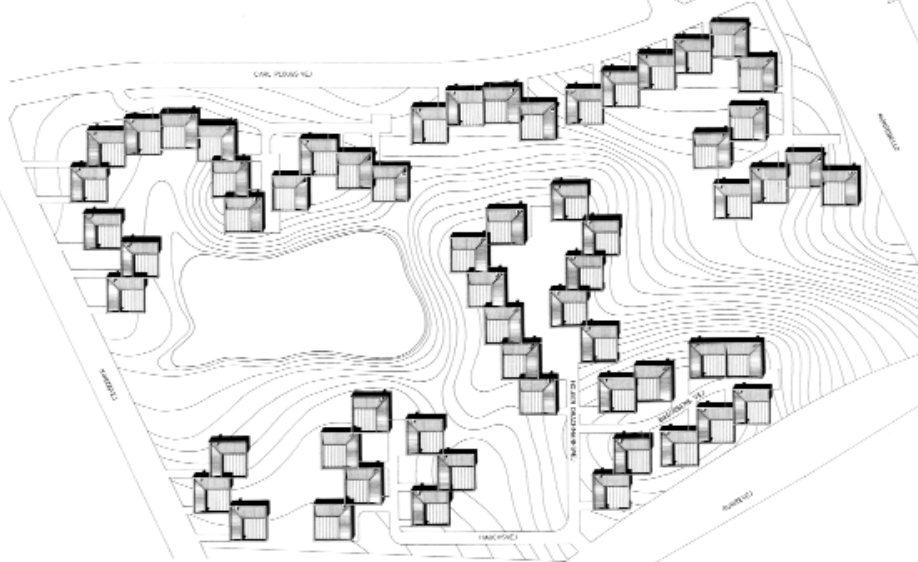

3 Plan of the Kingo Houses which, thanks to their courtyard forms, became known locally as the 'Roman' houses

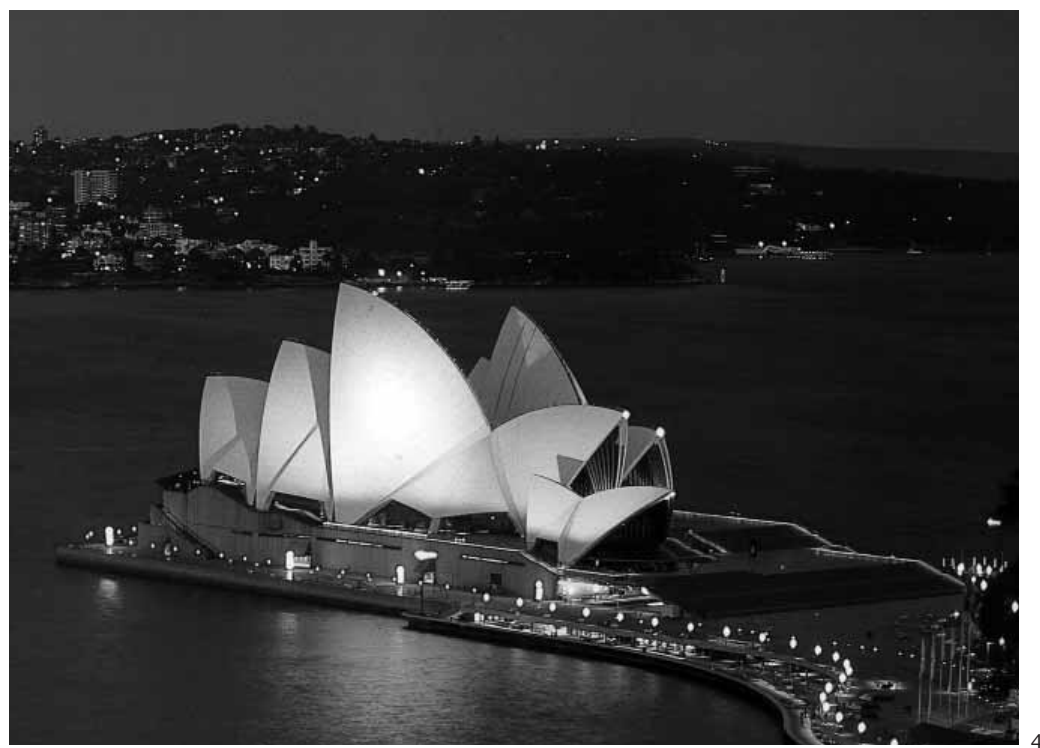

4 Night view of Sydney Opera House: the sculptural forms of the shells float above the geologically-inspired platform
Having built nothing larger than houses, in 1958 Utzon shot to worldwide fame as winner of the competition for Sydney Opera House. Although his entry was less developed than many, its appeal was obvious: the sculptural composition of the 'shells' floating above a masonry platform was a brilliant response to a site that could be seen from all sides and, courtesy of the great Harbour Bridge, also from above [4]; the great platform which housed all the non-public spaces resembled a piece of artificial geology, echoing the peninsula it replaced, and promised to become a remarkable public place; and finally the plan [5], uniquely among the 233 entries, placed the two theatres side by side rather than end to end. With its shared foyer-bars overlooking the harbour this was the only arrangement that took full advantage of the peninsular site, but it put the auditoria in a straightjacket that would later cause problems with fitting in sufficient seats.

On his arrival in Sydney Utzon was hailed as a hero, a 'tall Viking of a fellow' who reminded many of Gary Cooper or Edmund Hillary. It quickly became clear that the challenges of the project were far from purely architectural: conceived as the brainchild of a group of music-loving socialites, the Opera House had no formal client and no allocated funds; the main users were to be the symphony orchestra, with opera very much a secondary function; and the crucial political advocate, the Labour prime minister of New South Wales Joe Cahill, was in

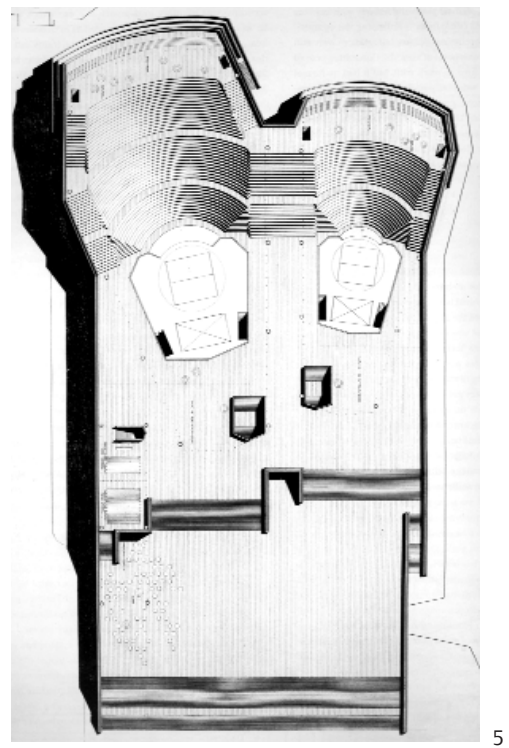

5 The finely rendered plan of the Opera House was the most finished of the competition drawings; Utzon alone among the 233 entrants placed the halls side by side 
danger of losing the next election and also suffering from a terminal illness. Utzon returned to Copenhagen convinced that nothing would come of it and spent the prize money on a lasting memento - a tapestry by Le Corbusier.

To his surprise the project did proceed and following his appointment as engineer Ove Arup's first task was to tell Utzon that the design could not be built as drawn [6]. The 'shells' were too tightly curved to work as the thin concrete in situ forms that Utzon, working without engineering advice, had envisaged, and they also lacked a calculable geometry. To meet a politically determined timetable - construction had to start before the next election work on the platform proceeded apace, its underside emerging as a tour de force of structurally expressive in situ concrete. Many, however, were worried that its vast size would prove 'inhuman', unable to imagine that the flights of ninety-metre-wide steps, uninterrupted by handrails, were destined to become part of a public space to rival the great piazzas of Italy, now home to concerts, ceremonies and political demonstrations of all kinds, as well as countless joggers and tourists.

After three years of increasingly fractious work on the superstructure, Utzon proposed a solution of the utmost simplicity: if all the 'shells' were cut from the same sphere, they could be made of identical precast concrete components [7]. Some in the Arup office thought that by opting for the most regular of curved surfaces Utzon had 'moved the goal posts', but the constructional logic was obvious and soon the site was transformed into a vast precasting factory presided over by several of the world's tallest cranes. Happily for Utzon's office, a new graduate named Rafael Moneo arrived from Spain equipped with skills in descriptive geometry to which Utzon's 'chief of staff', Mogens PripBuus, and other colleagues had not been exposed.

Utzon moved his office to Sydney early in 1963, intending to settle there permanently. With a view to establishing an ongoing practice he worked on other projects and entered invited competitions.
Amongst the latter the winning design for a new theatre in Zurich was outstanding, but eventually fell foul of local politics and the oil crisis of the early 1970s. Of his other designs, that for a museum in Silkeborg to house the works of the leading Danish modernist, Asger Jorn, achieved rapid fame thanks to its intriguingly 'organic' forms [9] which were, in fact, deeply indebted to a source with whom Utzon has rarely been associated -

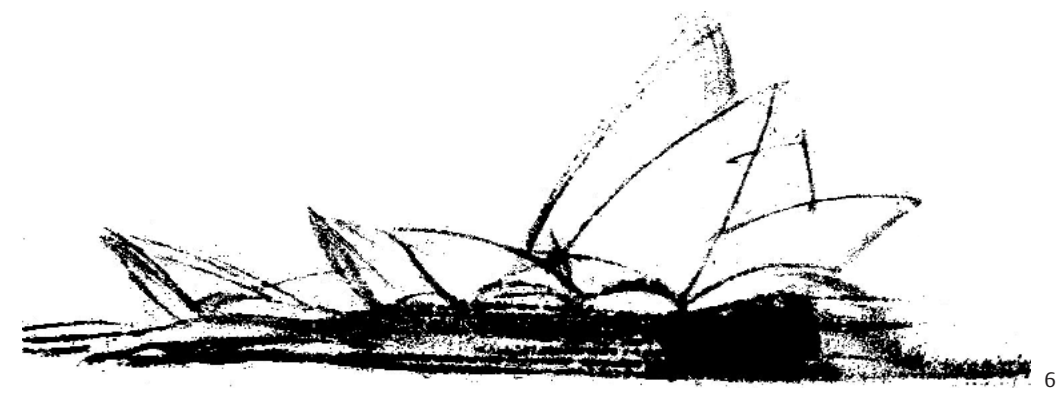

6 This drawings, made for the 'Red Book' presented to the client after winning the competition, is often described mistakenly as 'Utzon's first sketch' for the Opera House

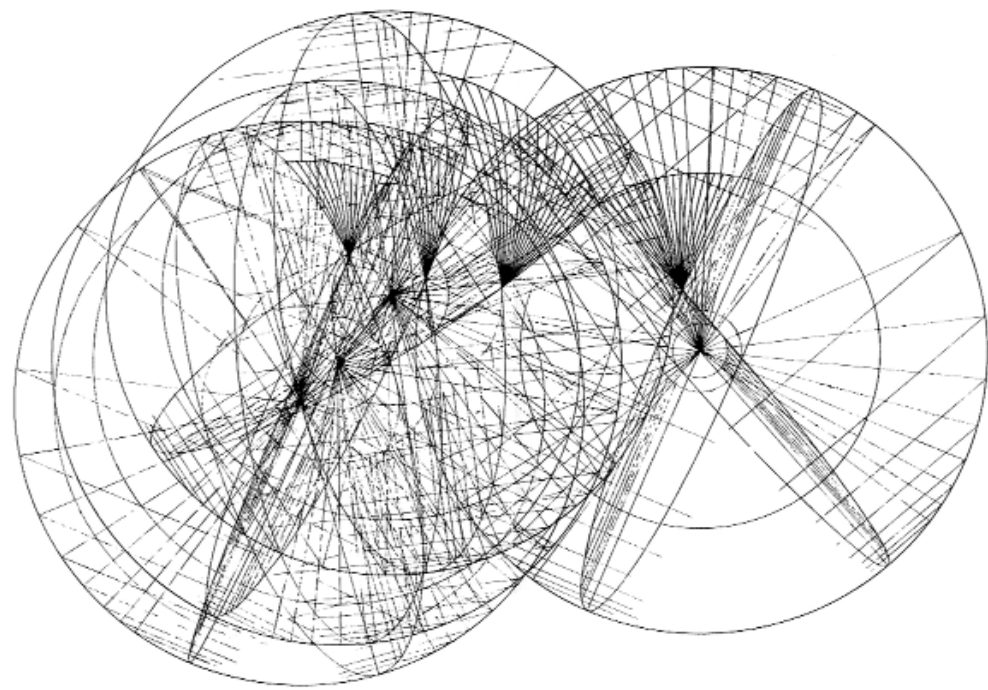

7 The drawings that defined the Opera House shells following the adoption of the 'spherical solution' were fiendishly complex constructions of circles and ellipses

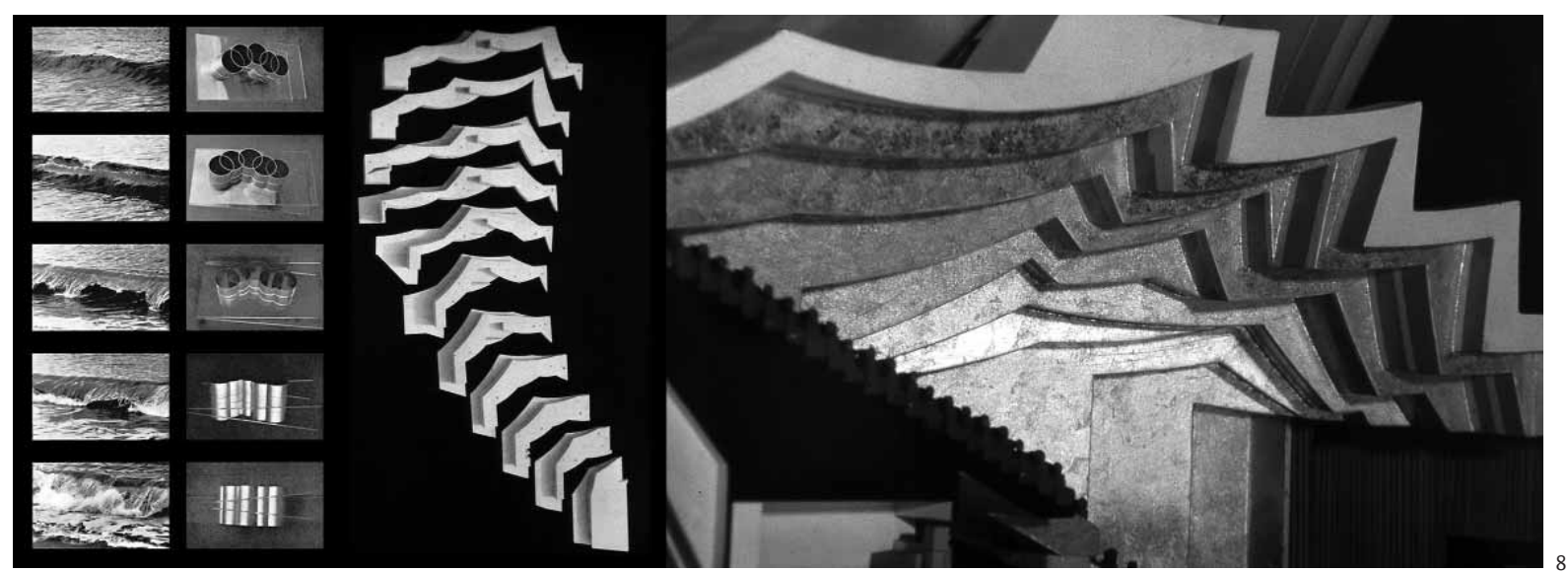

8 The acoustic ceilings for the Opera House, which were destined never to be built, were inspired by rolling waves. Recent computer modelling in Australia suggests that they would have been close to perfect acoustically 
Le Corbusier. Sainte-Baume and Ronchamp, La Tourette and the Firminy church all played their part, but were so artfully stolen as to escape detection for decades (arq 4/2, pp. 106-121).

The decision to cover the shells with tiles, inspired by the sight of domes and minarets gleaming above earth walls in the Middle East, was made at the outset, but it took three years to develop the right tile. Utzon explained to a Norwegian colleague, Helge Hjertholm, that he wanted to achieve a contrast like that between smooth, matte, newly-fallen snow, and the irregular reflective surface of earlier frozen layers. Eventually they settled upon a combination of unglazed tiles that were cut to follow the tapering profile of the structural ribs framing a matrix of square glazed tiles, which had the sought-after irregularity thanks to incorporating fragments of crushed tile in the otherwise smooth clay. The result is stunning: as you walk past them the shells variously glow, gleam or flash with light. Move closer, and individual tiles scintillate as if studded with stars. In the narrow 'street' between the halls you walk between soft blue shade and glistening ice, while in the shadows glow mysterious pools of light reflected from a sunny neighbour. And as the sun sets the light lingers, caressing and colouring the tiles: cream and ochre, then salmon pink and the palest of violets, until the voluptuous geometry is reduced to a ghostly silhouette.

In 1966, with the Opera House's structural problems solved but costs rising, the Labour Party lost the election to the conservative Country Party, who were determined to 'sort out the Opera House mess'. Although the mounting costs were always cited publicly as the major problem, in fact it was as much, if not more, a political battle for control and credit. Determined to make the project his own, the new Minister of Public Works, Davis Hughes, decided that Utzon needed to be reined in and insisted that he work as part of a design committee crucially, without overall design control. The terms were clearly unacceptable to Utzon. To force his hand his fees were withheld, and shortly after he resigned and left Australia, never to return.

Much ink has been spilled about the rights and wrongs of this sorry episode but for Utzon it came down to one issue: 'If my client could not trust me to do my very best for him,' he told me, 'there was no
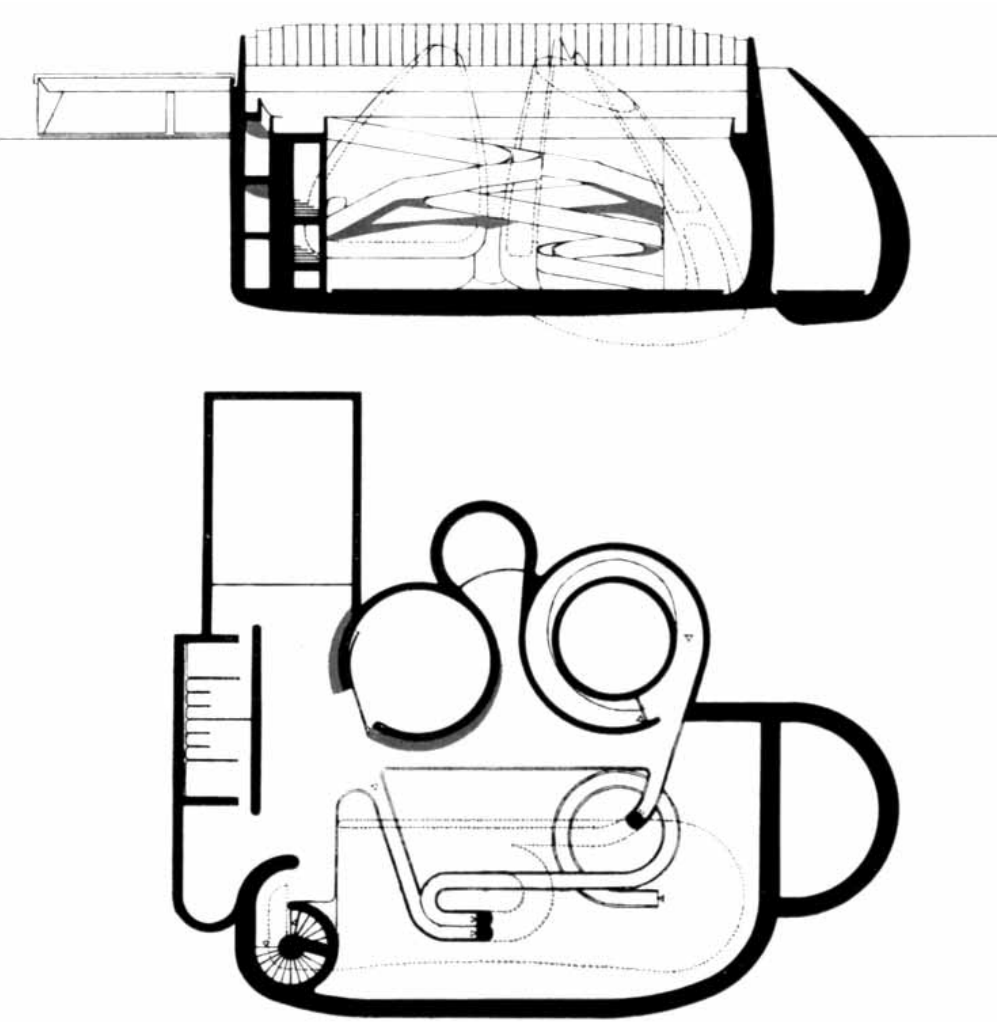

9 Silkeborg Museum: the most 'organic'-looking of Utzon's designs, its forms were deeply indebted to Le Corbusier

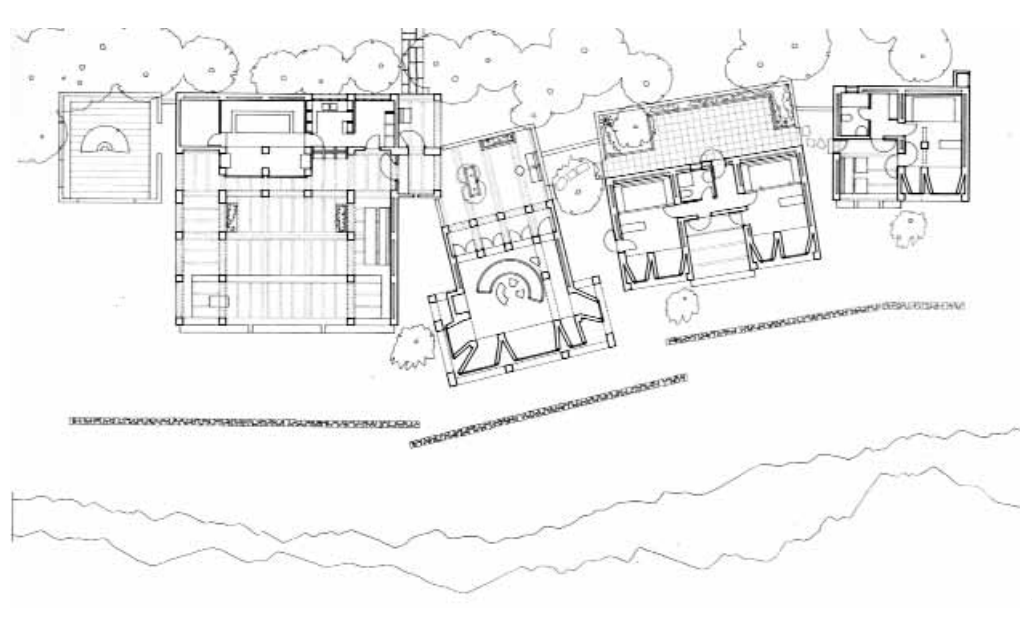

10 Can Lis, Utzon's first house on Majorca, was conceived as a settlement of small buildings

basis for continuing.' Several years later, wary of repeating the Opera House problems with the planned parliament building in Canberra, the Australian government commissioned a report on what had gone wrong. To their surprise it concluded that in almost every case where he was allowed free rein Utzon's 'method of experiment and collaboration produced a cheaper and more practical solution', and pointed out that some two-thirds of the final costs were incurred after his departure.

Back in Denmark, Utzon was legally bound by a confidentiality agreement - on pain of losing his fees - to say nothing about what had happened, and the New South
Wales government was free to suggest that he did not know how to complete the interiors, despite the fact that he had already published inspired preliminary designs for the acoustic ceilings in the Italian magazine Zodiac [8]. Seen as an embarrassment to the profession, Utzon was told that he could expect no work in Denmark. He continued to address the challenge of fitting sufficient seats into the auditoria, convinced that he would eventually be called back to complete the building, but there would be no invitation to return. And so, at the height of his powers, the most gifted architect of his generation in the world retreated to Hawai'i to teach at the university 


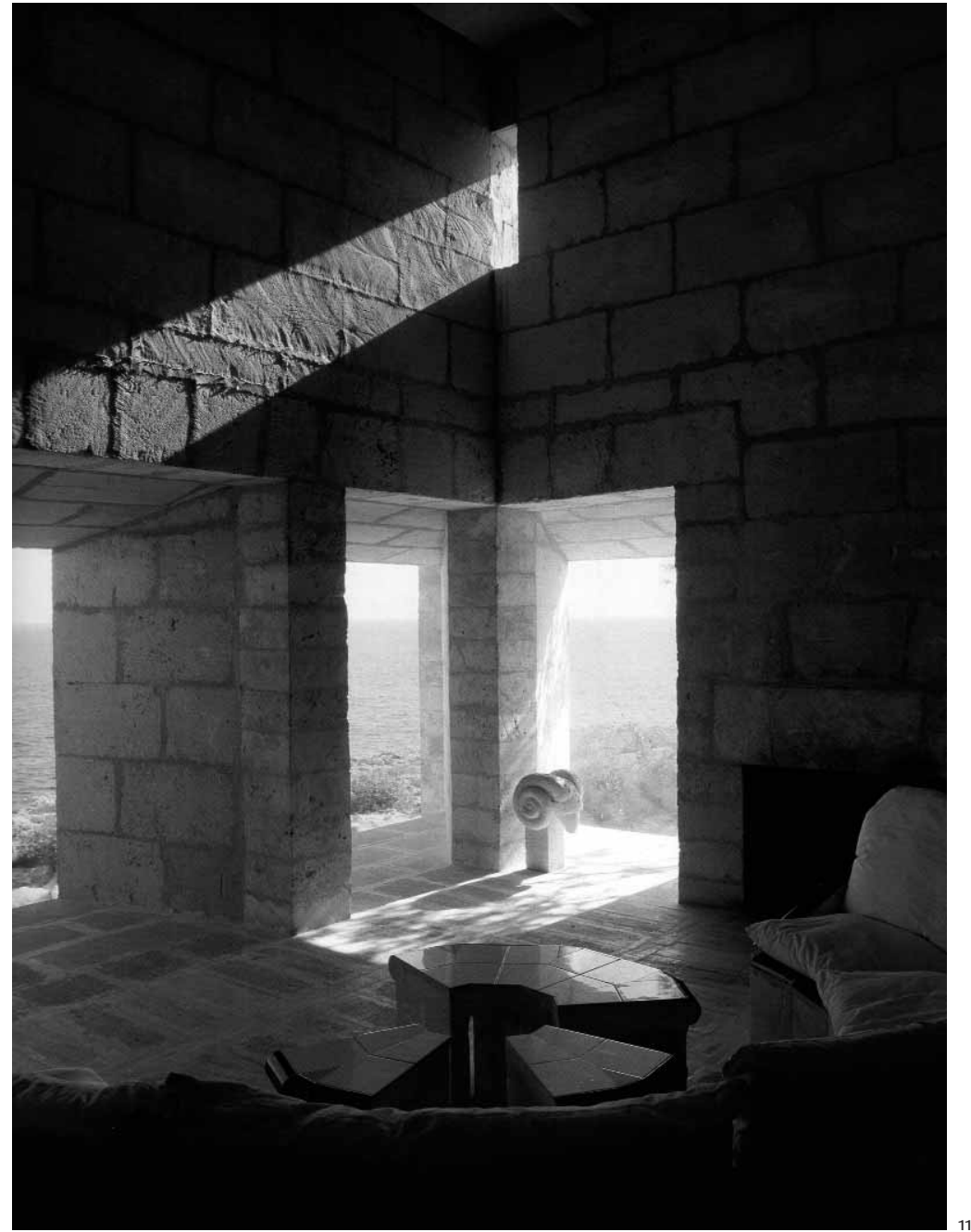

11 The living room of Can Lis is animated by a 'slice of the sun' as poetic as any in the history of architecture
- something for which he professed no real liking or talent - and to 'ghost' designs for hotels and apartments for a Danish architect he knew there.

Utzon decided to build a house named Can Lis, after his wife - on the first of two sites acquired on Majorca well before the tourist boom began; twenty years later, with tourism in full swing, the Utzons retired to a second, larger but architecturally less memorable design on the other, more remote, inland site. Perched on a cliff near Porto Petro, Can Lis was, Utzon said, conceived as a small settlement assembled from fragments of an 'ideal rectangle' that fell onto the site and then adjusted themselves to the horizon, to the topography and to each other [10]. Built using standard, locally available materials and components, the result is perhaps the most completely Mediterranean house of the twentieth century, thoroughly modern in its abstraction yet feeling as ancient as the Palace of King Minos [11].

Eventually one or two commissions came, notably for the church at Bagsværd, thanks to the visionary minister Pastor Svend Simonsen, and for the Kuwait National Assembly, courtesy of a limited competition orchestrated by Sir Leslie Martin, one of the judges for the Opera House. Utzon made sketches for both while
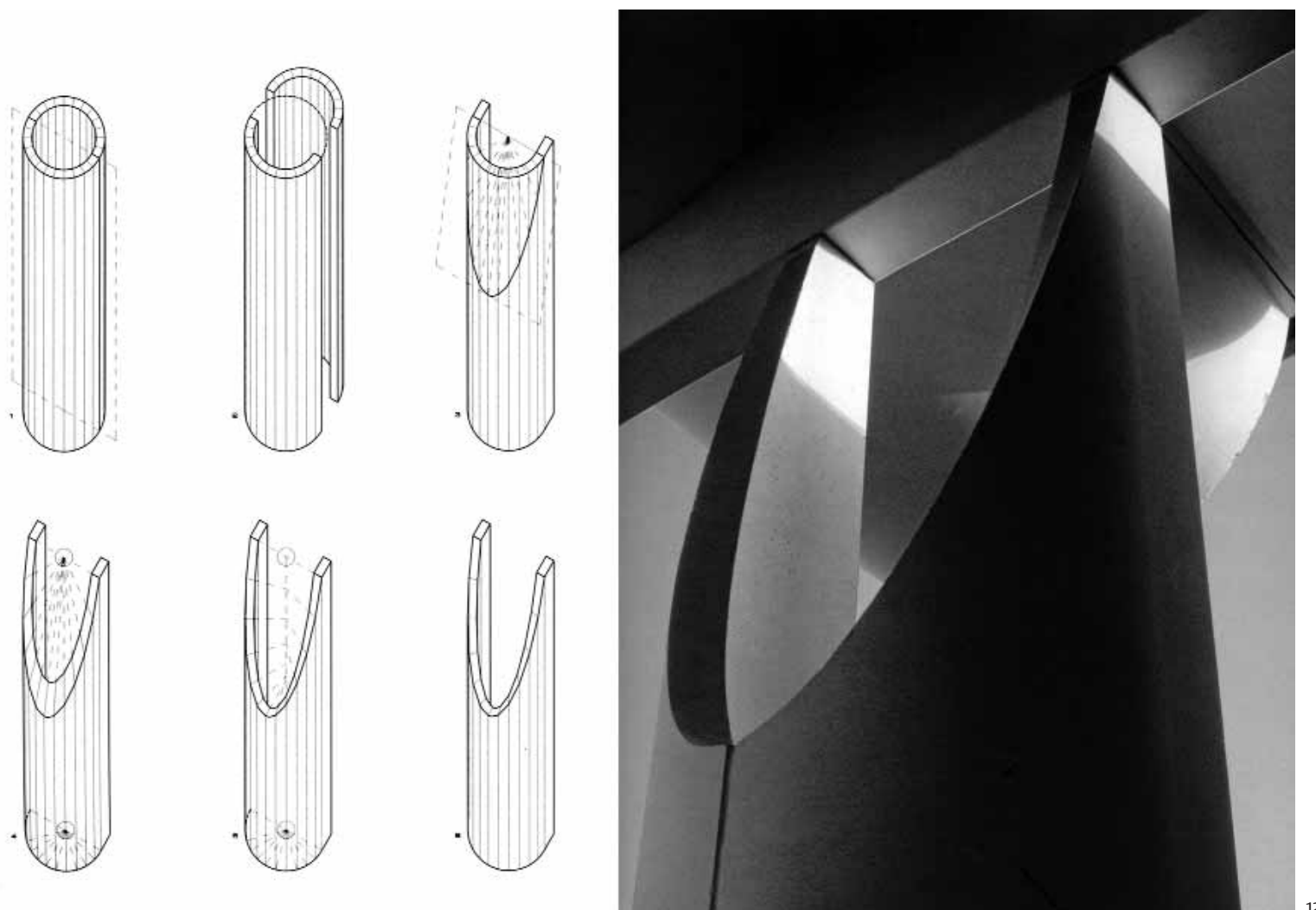

12 Column for the Kuwait Assembly Building - like the entire complex, an essay in cylindrical geometry 
working on Hawai'i, and these were drafted in London by a trusted former assistant from Turkey, Oktay Nayman, who was by then working on the British Library with Colin St John Wilson. Utzon turned the Kuwait project into a tour de force of precast construction using components generated by intersecting cylinders [12], while for the church he combined a precast frame of industrial directness with billowing in situ vaults inspired by clouds. Like Sydney it embodied a compelling image of the stability of the earth below and the fugitive life of the sky above while offering, as Utzon remarked, 'the reassurance of something above your head which is built, not just designed.' [13-14]

This distinction goes to the heart of Utzon's reverence for 'the nature of materials' and understanding of architecture as the art of building. When my monograph was nearing completion he telephoned to talk about an interview with Frank Gehry he had just heard on the BBC World Service: 'Mr Gehry explained how, thanks to computers, he can work like a sculptor and when he has the model exactly how he wants he hands it over to the engineers and says, "Now you work out how to build it".' After a pregnant pause, he went on: 'Is it clear enough in our book that I am a different kind of architect to Mr Gehry?' The misunderstanding had, of course, dogged his career ever since the Opera House shells proved unbuildable as conceived, leading to the widespread assumption that Utzon was interested in expressive form for its own sake, not logical structure. What he always wanted, as he put it in Sydney, was to work 'at the edge of the possible', pushing materials to the limits of their structural potential but always grounding the formal language in the discipline of construction.

Utzon learnt deeply from all the major masters of Modern architecture - from Le Corbusier and Mies, Wright and Aalto - as well as from his travels among the ancient civilizations of the world, and his buildings and projects, so varied in outward expression, are difficult to position neatly within those 'styles' and 'movements' beloved of historians. Born of a deep humanity, their ultimate model, to which he appealed repeatedly, was nature, and it is surely within that tradition of organic thought that we can trace back to Aristotle via Goethe that Utzon's work is ultimately to be understood. 'Through

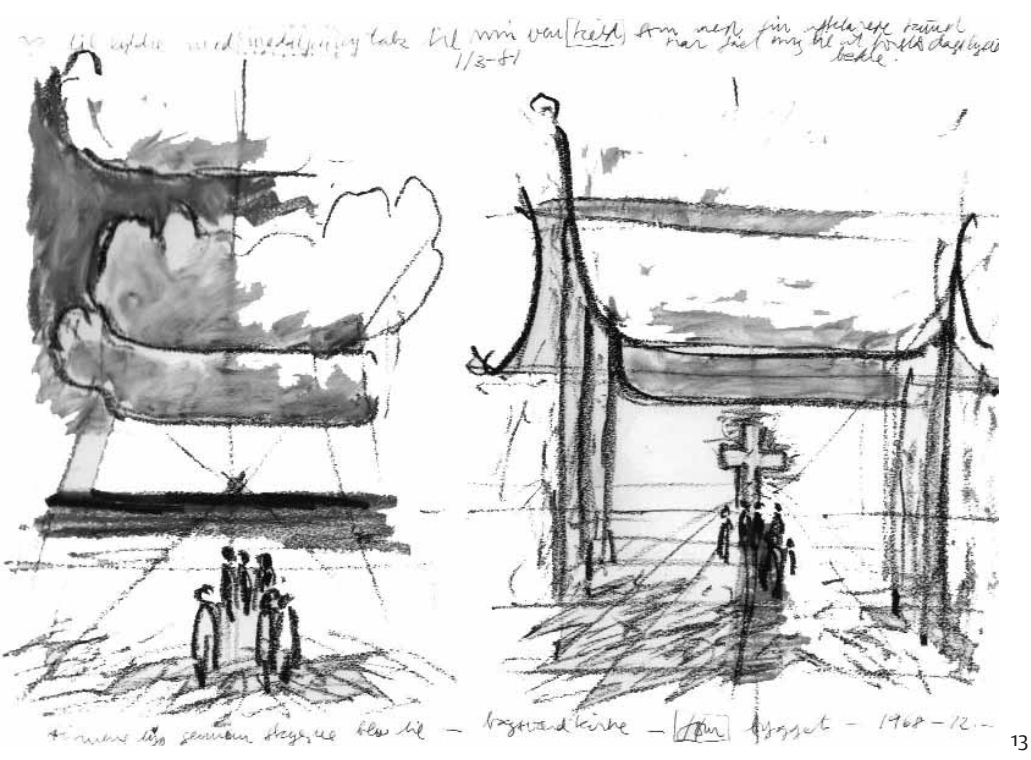

13 Sketch made for Christian Norberg-Schulz to illustrate the inspiration for Bagsværd Church

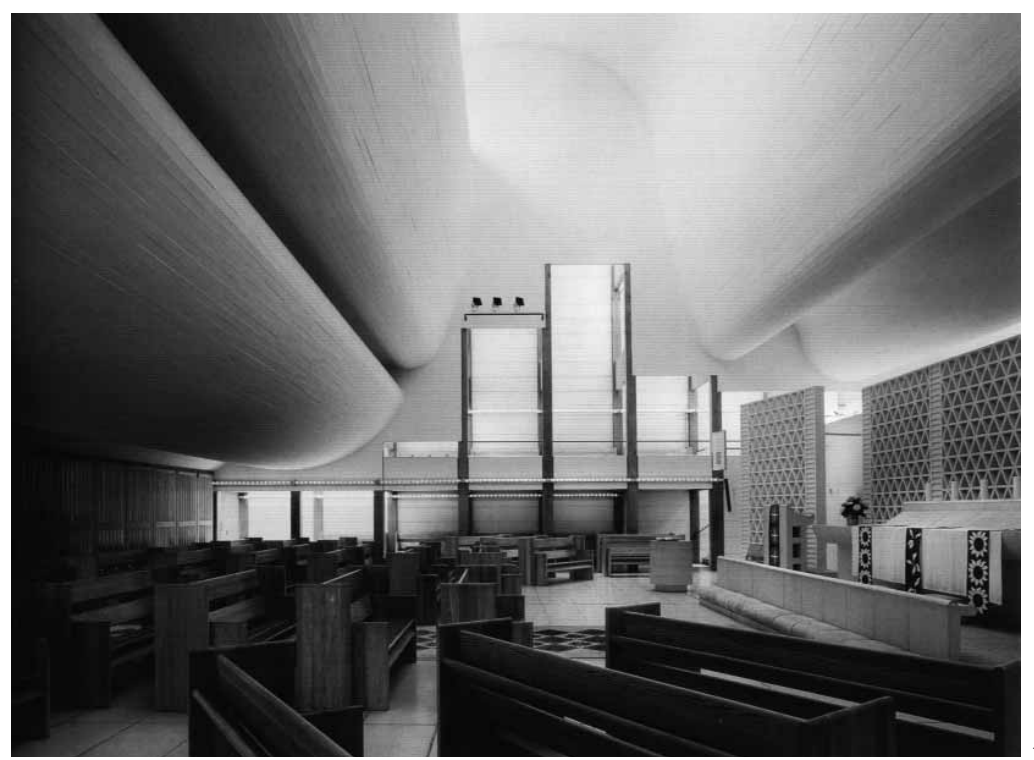

14 Interior of Bagsværd Church - 'built, not just designed'

contemplation of ever-creative Nature we might make ourselves worthy of participating intellectually in her productions,' observed Goethe, and by emulating nature's generative processes, not her outer forms, Utzon achieved what the painter Paul Klee described as 'a new naturalness, the naturalness of the work.' Despite all the artistry that went into their formation, you sense this quality in Sydney and Bagsvaerd, in Can Lis and the courtyard houses.

Utzon's place in history as designer of the most celebrated building of the twentieth century is secure. More importantly for the discipline, his small but potent body of work will live as long as architecture is valued: his legacy is ethical, not formal; a way of working, not a repertoire of forms.
Jørn Utzon is survived by his wife; two sons, Jan and Kim, both architects; and a daughter, Lin, a designer and artist.

RICHARD WESTON 